\title{
Lawyers, Judges, and Related Workers
}

National Cancer Institute

\section{Source}

National Cancer Institute. Lawyers, Judges, and Related Workers. NCI Thesaurus. Code C122471.

Lawyers advise and represent individuals, businesses, and government agencies on legal issues and disputes. Judges and hearing officers apply the law by overseeing the legal process in courts. They also conduct pretrial hearings, resolve administrative disputes, facilitate negotiations between opposing parties, and issue legal decisions. 